\title{
硬膜外脊䯣刺激療法中の鍼通電治療
}

\author{
田中 正史 ${ }^{\mathrm{a}}$ 豊田宏 ${ }^{\mathrm{a}}$ 廖英和 ${ }^{\mathrm{a}}$ \\ 三宮 正博 $\mathrm{b}$ 綿貫 実 $\mathrm{b}$ \\ a 藤村病院ペインクリニック・東洋医学科, 埼玉, † 362-0035 上尾市仲町1-8-33 \\ b 綿貫鍼炎院，埼玉， $=362-0035$ 上尾市仲町1-7-27

\section{Acupuncture Treatment for the Patient with Spinal Cord Stimulation}

\author{
Tadashi TANAKA $^{\mathrm{a}}$ Hiroshi TOYODA ${ }^{\mathrm{a}}$ Hidekazu RYO $^{\mathrm{a}}$ \\ Masahiro SANNOMIYA ${ }^{\mathrm{b}} \quad$ Minoru WATANUKI $^{\mathrm{b}}$
}

a Department of pain clinic and oriental medicine, Fujimura Hospital, 1-8-33 Naka-cho, Ageo, Saitama 362-0035, Japan

b Watanuki Acupuncture Clinic, 1-7-27 Naka-cho, Ageo, Saitama 362-0035, Japan

\begin{abstract}
We experienced a case of chronic pain responding to electrical acupuncture therapy while on spinal cord stimulation. A 35 year-old male presented with chronic neck pain. At 16 years of age, he had neck pain due to traffic accident with stellate ganglion block and epidural block. At 29 years of age, he sensed radiating pain in the 3 rd to 5 th digits of the left hand during epidural block. At 33 years of age, nerve root injury occurred after insertion of an epidural catheter, resulting in epidural abscess. Although the abscess resolved after antibiotic treatment, he had stiff fingers in the left hand together with neck pain and restricted range of motion of the neck. At 34 years of age, a spinal cord stimulation device was inserted which improved the stiff fingers in the left hand, but not the neck pain and restricted neck motion. He therefore visited our institute. At presentation, neck pain together with dysphagia and mastication pain were observed, and the patient was on a liquid diet. He was given electrical acupuncture treatment in additional to trigger point block and stellate ganglion laser. After two treatments, he was able to resume a normal diet. With reduced neck pain, he also undergo rehabilitation mainly through voluntary neck movements. This case demonstrates that electrical acupuncture treatment may be safe and effective for patients fitted with spinal cord stimulation device.
\end{abstract}

Key words : spinal cord stimulation, electrical acupuncture therapy, neuropathic pain, chronic pain, rehabilitation

\section{要旨 \\ 硬膜外脊膸刺激療法中の患者に鍼通電治療が有効であった 1 例を経験した。症例は35歳の男性で，16歳時からの 交通外傷などによる頸部痛に対し，星状神経節ブロック，頸部硬膜外ブロックを施行されていた。29歳時の硬膜外 ブロック時に左第3〜5指に放散痛を生じ，33歳時の硬膜外力テーテル挿入後に硬膜外膿瘍を発症した。抗生剤に て軽快したが，以降左手指のこわばりとともに頸部痛・頸部後屈制限が著明となり34歳時に硬膜外脊䚛刺激電極を 挿入された。左手指のこわばりは改善したが頸部痛，頸部後屈制限が改善されないため来院した。頸部痛に加え嶼 下・咀嚼時痛があり流動食摂取の状態であったが, トリガーポイントブロック, 星状神経節近傍照射に加え, 後頸 部に鍼通電治療を施行したところ，2 回の施療により常食椇取が可能となった。頸部痛の軽減に伴い自発運動を主 体としたリハビリテーションを行っている。硬膜外脊䀯刺激療法中にも鍼通電治療は安全に行うことができる可能 性がある。}

キーワード：硬膜外脊髄刺激療法，銊通電治療，神経因性疼痛，慢性疼痛，リハビリテーション

\section{緒言}

硬膜外春髄電気刺激療法 (Spinal Cord Stimulation ; SCS）は慢性難治性疼痛, 特に虚血性疼痛や神経因 性疼痛に有効であると言われている
疼痛は，薬物療法及び神経ブロックなどの治療によ り充分な鎮痛・除痛効果が得られない体幹及び四肢 の慢性疼痛とされている。一般名称は脳・脊髄電気 刺激装置であり, 類別としては理学診療用器具と 
なっている。電気刺激装置であるため, ペースメー カー同様医療用電気治療機器はSCS 誤作動させ る可能性がありその使用がためらわれる。今回われ われは, 硬膜外脊髄刺激療法中の患者に対し, 銊通 電治療を安全に施行することができ，良好な結果を 得たので報告する。

\section{症例}

症例：35歳, 男性, 会社員（休職中）

主訴：頸部痛, 嚥下·咀嚼時痛, 頸部運動制限 (特 に後屈制限)

家族歴・既往歴：特記事項なし

現病歴：1983年から1988年までの数回の交通事故 などによる頸部痛に対し，整形外科で斢引・理学療 法を受けていたが軽快せず，1994年からは星状神経 節ブロックに加え頸部硬膜外ブロックを受けていた。 1997年12月の頸部硬膜外ブロック時に左上腕から指 先にかけての激痛を自覚した。以降もブロック治療 は継続され，左上肢の痛みはほほ消失するも左第 3 〜 5指にしびれ，冷感を伴うこわばりが残った。 2001年 3 月に再度交通事故により外傷性頸部症候群 と診断され, 約 6 力月の加療にても頸部運動制限

（特に後屈制限）を伴う頸部痛が残ったため症状固 定と診断された。同年11月頸部硬膜外カテーテル挿 入後から熱発し硬膜外膿瘍を形成した。抗生剂にて 軽快したがこのとき硬膜外春髄刺激電極の説明を受 け，12月に米国メドトロニック社製の完全植込型神 経刺激装置アイトレル 3 の留置術を施行された。硬 膜外脊髄刺激電極の使用により左手の泠感，こわば りは消失したが頸部痛，頸部運動制限は残った。ソ セゴン，レペタン投与にても頸部痛は改善せず, 弱 オピオイドであるコデインを $400 \mathrm{mg} /$ 日投与された が疼痛コントロールは不十分であった。大学病院で のドラッグチャレンジテストを受けるまでのベッド 待ちのため 2002 年 10 月当院紹介入院となった。

入院時の身長は $172 \mathrm{~cm}$, 体重 $58 \mathrm{~kg}$ 。頸部は常に前 屈した状態（図 1 a) であり，0 度位を保持すると 苦悶様の表情となる（図１ｂ）。また嚥下・咀嚼時 痛のため食事は流動食のみ摂取可能な状態であった。 しかし栄養状態は比較的良好で，血液その他の検査 では異常は見られなかった。腹直筋の緊張が見られ， 脈は緊，舌には軽度の白苔が見られた。左側腹部に はSCSのパルス発生装置が埋め込まれており, 傍 春椎部にはリード線が埋め込まれていた。

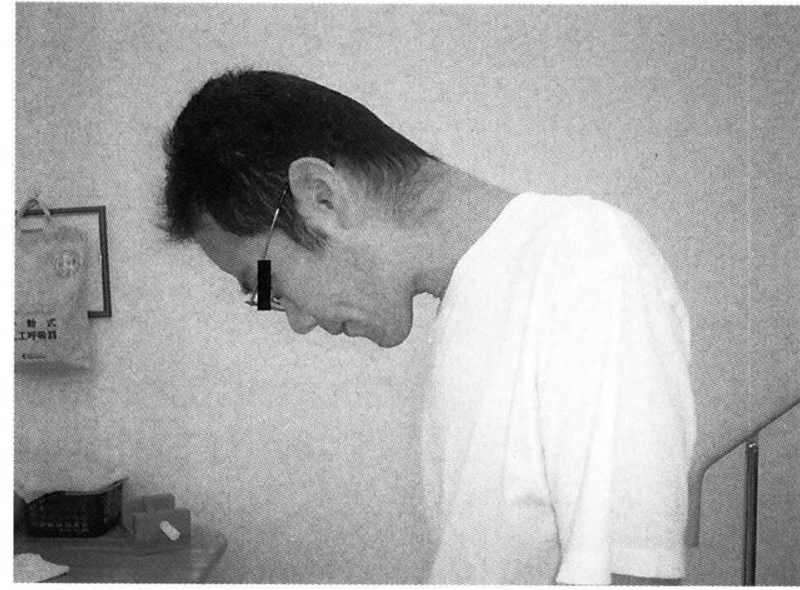

図 1 a

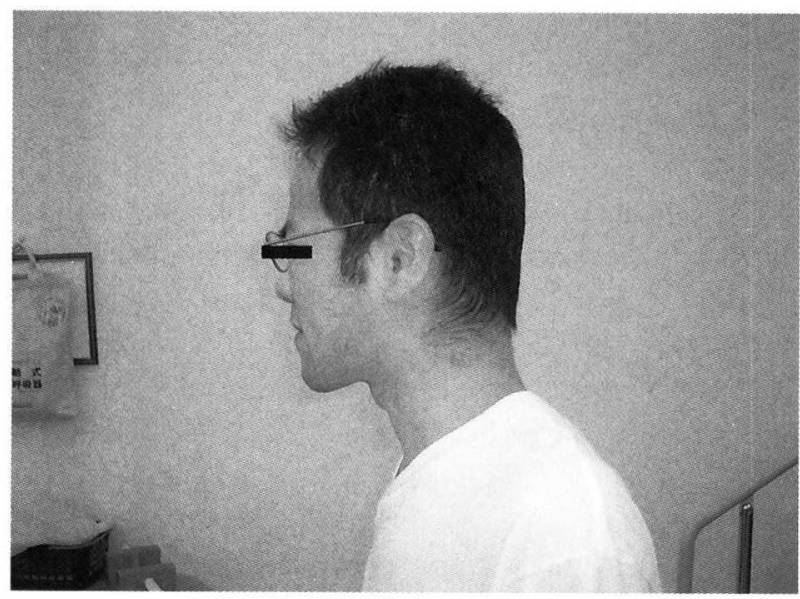

図 1 b

SCS による電気刺激は OFFにすると左手のこわ ばりが出現するため常に ON の状態であった。当院 ではトリガーポイントブロック，スーパーライザー による星状神経節近傍照射に加え，以前当院に入院 した際，鍼通電治療を経験していたため患者の希望 により後頸部に鍼通電治療を施行した。天柱，肩井， 肩中俞, 肩外愈, 天宗, 肺俞, 心俞, 膈兪の 8 穴を 選穴し，カナケン株式会社製ステンレス製 $25 \mathrm{~mm} \times$ $0.3 \mathrm{~mm}$ ディスポーザブル鍼（日本式 8 番）を使用 した。刺鍼の深さは $10 \mathrm{~mm}$ 程度とし， $1 \sim 2 \mathrm{~Hz}, 5$ $\mu \mathrm{A}$ の程度の刺激で15分間通電した。刺鍼は傍脊柱 部に触狄るSCS のコードを確認しながら傷つけな いように慎重に行った。腰部の銊通電治療を施行し たときは，左側腹部に埋め达まれているパルス発生 器を挟んで刺激しないように注意した。当初 SCS の刺激中は䛊作動の可能性があると考え，電気刺激 をOFFにした状態で鍼通電治療を施行したが，ON の状態でもなんら問題なく鍼通電治療が施行できる ことが判明した。以降は電気刺激を ON の状態で銊 


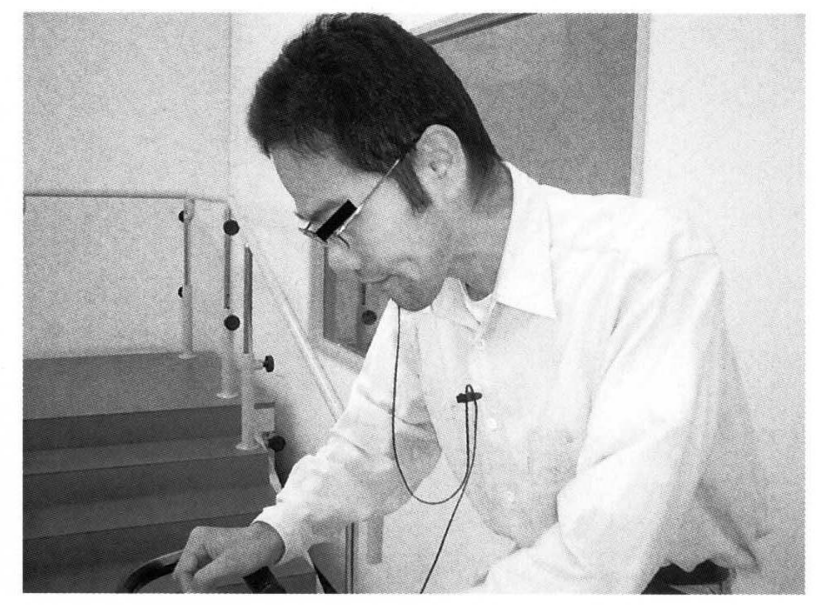

图 2

通電治療を施行した。2 回の施療により嚥下・咀嚼 時痛がVASにて10から 2 程度まで改善したた め, 常食摂取が可能となった。可動域を拡大させる ため, 主に自発運動を主体としたリハビリテーショ ンを行い， 0 度位保持での作業訓練を行った。約三 カ月の入院で, 24 回の鍼通電治療により頸部痛はあ るものの 0 度位保持でのリハビリテーションは可能 となり（図 2 ), 日常生活は問題ないと判断されド ラッグチャレンジテストを受けるため大学病院へ転 院となった。

現在, 頸部痛に対しては大学病院でのケ夕ミンに よるドラッグチャレンジテストにも反応せず，モル ヒネの導入が検討されている。

\section{考察}

SCS は1967年にShealy らよって癌性疼痛に対 する除痛効果が報告され²), 本邦では神経ブロック や外科的治療に反応しない慢性難治性疼痛に対し, 1992年に保険適応となった。SCS の作用機序とし ては, 春髄電気刺激時に疽髄後角内に抑制性伝達物 質である GABA や glycine が放出されることが明ら かにされている ${ }^{3 / 4)}$ 。SCS は慢性疼痛のなかでも特 に神経因性疼痛に有効であると言われており, 帯状 疮疹後神経痛や断端痛などに効果がある。しかし神 経因性疼痛で軀幹や四肢の痛みであっても, 春䯣上 位が起源である場合にはSCS は無効であると言わ れている5 。

SCS の使用環境は家庭電化製品, 電子レンジ, 電気工具などでは影響を受けない。しかし携帯電話 は米国における試験しか行われていないため, 国内 の新機種の携带電話に対する影響は不明である。業 務用電気機器（アーク溶接具などの営業用電気機器,
高出力アマチュア発信機などの通信機器）および高 圧電線, 変電所は近づきすぎると䛊作動する可能性 がある。公共図書館, デパート, 空港等に設置され た盗難探知器はパルス発生装置のスイッチを ONあ るいは OFFに切り替えてしまう可能性があり，ま た刺激が一時的に増加して患者が「ショックを受け る」もしくは「ぎょっとする」などと訴えることが ある。MRIやデマンド型ペースメーカー, 体外式 徐細動器, ジアテルミーなどの医療機器は誤作動の 可能性があり併用禁忌となっている。また放射線照 射治療や結石破砕装置, 走査形超音波診断装置, 電 気メスなどは併用注意となっている。今回鍼通電治 療に使用したのは理研医療電機株式会社製のノーベ ルパルス RP-5であり, 米国メドトロニック社の国 内販売会社によると, 併用注意ではあるがパルス発 生装置を挟んで刺激しなければ大丈夫であろうとの 回答を得たため施療に至った。患者は入院当初「全 然動く気のしなかった頸椎」と表現していたが，三 カ月の入院で「上手にイメージすれば後屈できるよ うになった」と回答しており, 䛊作動もなく安全で ある可能性があり有効な治療であったと考えられる。

今回の症例の疼痛には二つの機序が考えられる。 一つは1997年12月の硬膜外ブロック時に生じた左手 に放散する痛みを感じたとき, すなわち神経根損傷 と考えられる機序，もう一つは頻回の交通事故によ り生じた上位春髄の損傷によると考えられる頸部痛 である。神経根損傷による左手の疼痛, こわばりは SCS 挿入, 刺激により自制内となったが, 金髄損 傷によると考えられる頸部痛にはSCS は無効で あった。これは春髄上位が起源である痛みの場合に

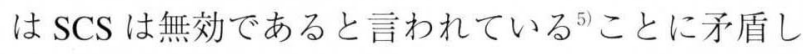
ない。この難治性頸部痛の関連痛として咀嚼時に疼 痛が生じるため, 與下困難をきたし, 流動食摂取し かできなくなったと考えられる。嚥下困難であれば 類経戝翼の喑膈方として天突, 膻中, 中府, 膈俞な どが選穴される 選穴されるが, この患者の場合, 常に頸部が前屈し た状態であり刺銊も困難であったと考えられる。

この患者の場合, 長期間の疼痛によるうつの合併 も考えられる。うつはWHO の銊治療が試みられて いる47疾患にも含まれている。松森は「黄帝内経」 の治神論からうつの全身治療として, 頸肩こりの治 療, 睡眠促進法, 食欲・便通の改善法をあげ, 治神 
穴として天柱, 風池, 肩井, 身柱, 心俞, 膈兪など をあげており7，今回の選穴と重なる部分も多い。 この患者は弱オピオイドであるコデインを使用する までは非ステロイド性消炎鎮痛剤を長期に使用して いたと考えられる。非ステロイド性消炎鎮痛剂の添 付文書には抑うつがあり，診察，問診上は感じられ なかったがうつの合併は否定できない。抗うつ薬は 慢性疼痛における有用性が示されている薬剤であり， 用量依存性に鎮痛効果が得られると報告されてお $り^{8)}$, SDS (Self-rating Depression Scale) などによる うつの診断が必要であったと考えられる。

慢性疼痛に対しては薬物療法が基本となるが, 理 学療法や精神療法, 患者教育などの薬物以外の治療 を組み合わせて治療するのも有効であると報告され ており ${ }^{9)}$, 今回のように薬物療法に加え, ペインク リニック, 東洋医学, リハビリテーションを組み合 わせて治療に臨んだことも著効を示した理由だった と考えられる。

\section{結語}

SCS 挿入中の患者に対し，鍼通電治療を安全に 施行することができ有効であった。SCS 挿入にて も軽快しない慢性疼痛患者に対し，ペインクリニッ ク的処置（トリガーポイントブロック，星状神経節 近傍照射, キセノンレーザー), 鍼通電治療, 自発 運動を主体としたリハビリテーションにより頸部痛 は残ったが頸部運動制限は日常生活上問題ないレべ ルにまで改善した。

付記 : 本論文の要旨は第54回日本東洋医学会学術 総会（2003年，福岡）に扔いて報告した。

\section{文献}

1) Meyerson B, Linderoth B, Lind B : Spinal cord stimulation in chronic neuropathic pain. Lakartidningen, 88, 727-732 (1991)

2 ) Shealy CN, Mortimer TJ, Reswick JB : Electrical inhibition of pain by stimulation of the dorsal column. Anesth Analg, 46, 489-491 (1967)

3 ) Cui JG, Linderoth B, Meyerson BA : Effects of spinal cord stimulation on touch-evoked allodynia involve GABAergic mechanisms. An experimental study in the mononeuropathic rat. Pain, 66, 287-295 (1996)

4 ) Cui JG, O'Connor WT, Ungerstedt U, et al : A spinal cord stimulation attenuates augmented dorsal horn release of excitatory amino acids in mononeuropathy via a GABAergic mechanism. Pain, 73, 87-95(1997)

5 ）村川和重：硬膜外脊髄刺激療法が役立つのはどの ような疼痛患者なのか一適応疾患と選択基準につ いてー, ペインクリニック， 21，508-515 (2000)

6 ) 千葉勝吾, 山内雅之, 石川家明ほか：臨床鍼尒処 方(13)一肝系統の病症処方 (二) 一, 東洋医学, 22, 54 -57 (1994)

7 ) 松森裕司：罂状態に対する鍼尒治療，日本東洋医 学雑誌, 54(1)，161-168 (2003)

8 ) McQuay HJ, Tramer M, Nye BA, et al. : A systemic review of antidepressants in neuropathic pain. Pain, 68, 217-227 (1997)

9 ) Allegrante JP: The role of adjunctive theraphy in the management of chronic non-malignant pain. Am $\mathbf{J}$ Med, 101 (suppl 1 A), 33S-39S (1996) 